症例

術後10年でリンパ節再発をきたした stage IV 結腸粘液癌の 1 例

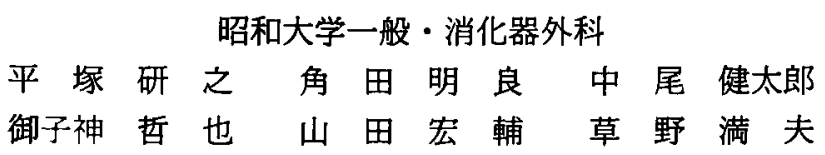

症例は79歳男性. 1992年 8 月上行結腸癌に対し右半結腸切除を施行した。病理組織猃 断は粘液癌であった。

術後, 経口抗癌剤を 1 年間内服し外来経過観察を継続していた.

2002年11月下痢, 体重隇少を認め来院し, 血液生化学検査で CEA の急激な上昇がみら れた。内視鏡上は明らかな再発，原発巣の所見なく，胸腹部 CT て胸腔内および腹腔内 リンパ節の腫大を認めた。さらに, Virchow リンパ節の腫大があり, 吸引下針生検で class V と診断された. 標本中に腺管形成傾向と粘液産生傾向を認め, 結腸癌転移再発と 診断した。同年12月より全身化学療法を施行したが，奏効せず癌悪液質で平成15年 5 月 永眠された。

高度進行大腸癌長期無再発生存後の再発例は非常に稀であり，若干の文献的考察を加 え報告する。

索引用語 : 長期無再発後再発, 大腸癌, 粘液癌

\section{緒 言}

大腸粘液癌は他の組織型と比較し予後不良とされる が, その経過についてはまだ不明膫な点も多い。また， 大腸癌において一般的に無再発 5 年生存であれば，ほ ほ再発の危険性はないと考えられているが, 長期経過 後再発をきたした症例も散見される。今回われわれは， 高度に進行した大腸粘液癌が10年生存後再発したと思 われる稀な症例を経験したので, 若干の文献的検討を 加元報告する. 症例の臨床病理学的記載は, 大腸癌取 扱い規約（改訂第 6版） 1)に従った。

患者：79歳, 男性.

$$
\text { 症例 }
$$

主訴：特になし。

既往歴：肺結核, 糖尿病, 高血圧.

家族厢：特記すべきことなし。

現病歴：1992年 8 月，69歳時下血精査で上行結腸癌 と診断され, 右半結腸切除を施行した。病理組織診断 は Type 1, muc, ss, n4 (No.216), P0, H0, ly3,

2004年11月26日受付 2004年12月 6 日採用

〈所属施設住所〉

干142-8666 東京都品川区旗の台 $1-5-8$ vl, stage V (IV) であり, 根治度 $\mathrm{B}$ の手術が行われ た. 術後, 経口抗癌㓣を 1 年間内服したのち外来経過 観察を継続していたが，2002年 3 月，経過良好にて外 来担当医が変更になったのを機に外来 follow を中止 とした. 同年 8 月, 呼吸困難にて当院内科受猃, 肺気 腫の診断をうけたがこの際胸部 CT 上リン八゚節腫大は みられなかった。同年11月下痢, 体重減少を認め再診 し, 血液生化学検査で CEA の急激な上昇がみられた。 上部下部内視鏡検査では明らかな再発, 原発巣の所見 なかったが, 胸腹部 CTで胸腔内および腹腔内リンパ 節の腫大を認めた，さらに，Virchow リンパ節の腫大 があり，吸引下針生検を施行したところ class V と診 断され，治療目的て入院となった。

入院時現症：身長 $160 \mathrm{~cm}$, 体重 $55 \mathrm{~kg}$, 筫血黄疸なく, 左頸部に約 $1 \mathrm{~cm}$ 大, 無痛性で可動性のある弾性硬の 腄瘤を触九た。その他に腫瘤は触知しなかった。

入院時検查所見 : CEA が $14 \mathrm{ng} / \mathrm{ml}$ と上昇を示す他 に異常值はみられなかった。

原発巣の肉眼標本所見：type $1,2 / 3$ 周性の隆起性 病変を認める(図 1 )。

原発巣の病理所見：多量の粘液産生, 高度のリンパ 管侵襲，多彩な分化像を認める（図 $2 ， 3$ ）。 


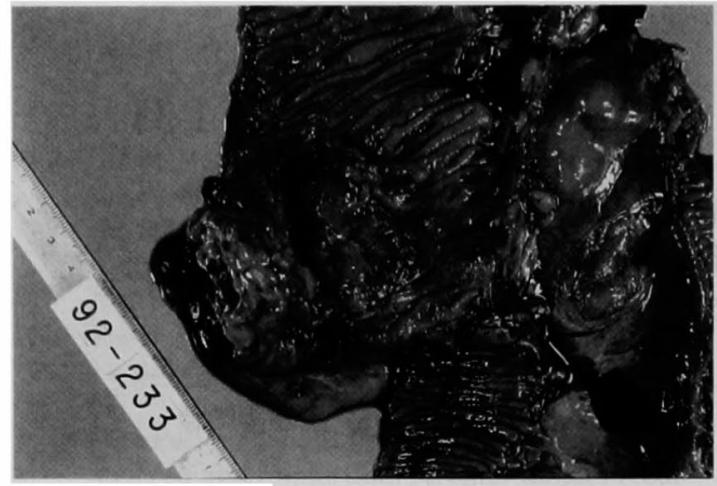

図 1 原発宩の肉眼標本所見 : type 1，2/3 周性の隆起 性病変.

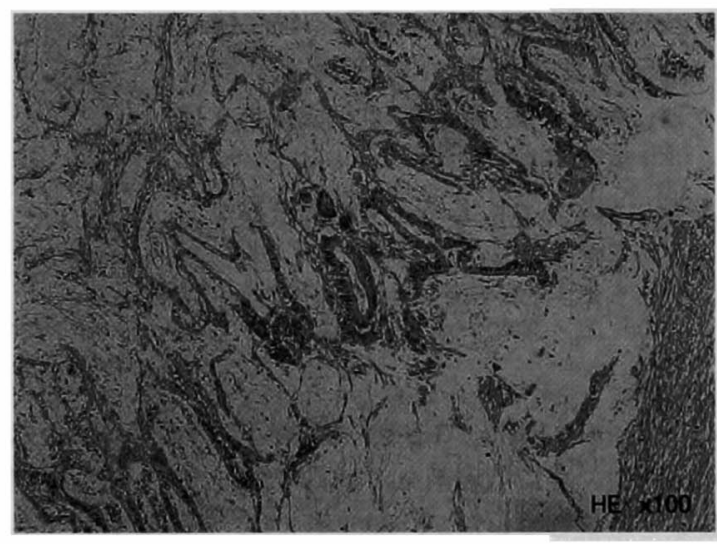

図 2 原発巣の病理所見 $1:$ 細胞外に多量の粘液産生が あり，一部腺管構造を認める。

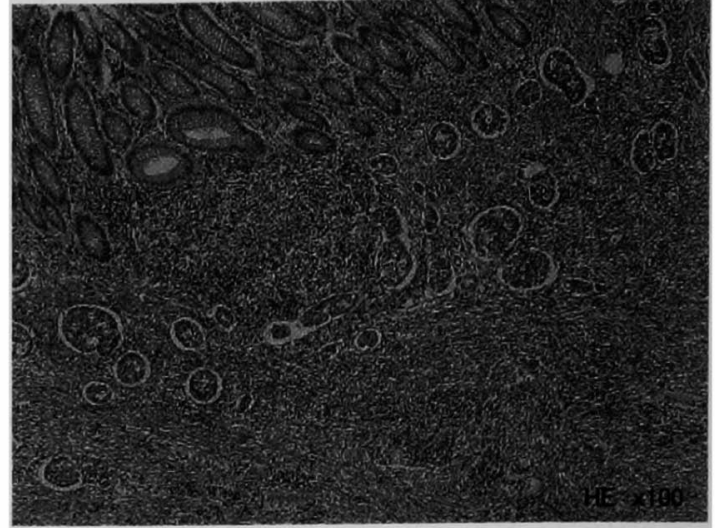

図 3 原発巣の病理所見 2 : 高度なリンパ管侵襲と多様 な分化傾向を示す.

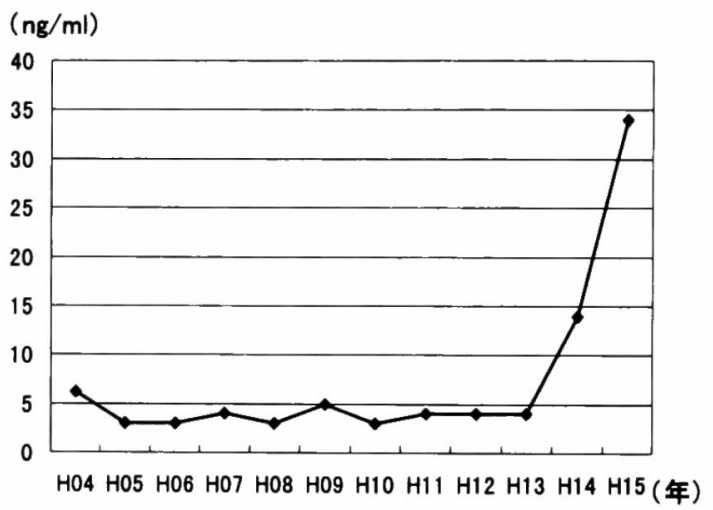

図 4 血清 CEA 值の推移

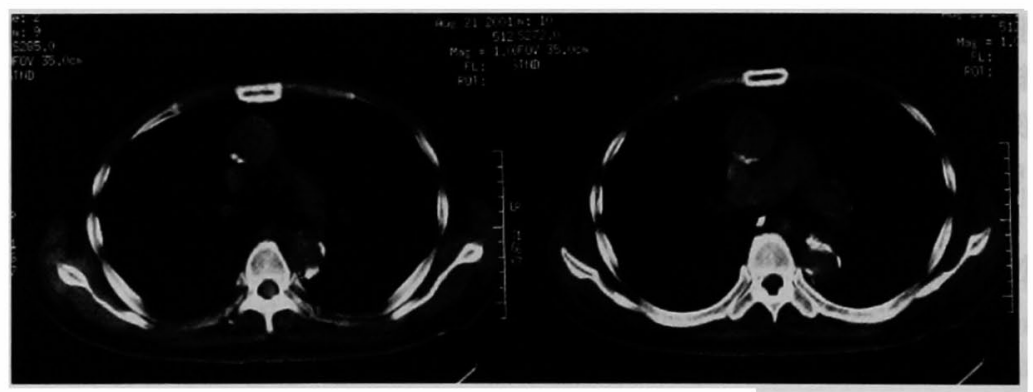

図 5 平成13年時胸部 CT 所見：緃隔内リンパ節の明らかな腫大は認めない.

血清 CEA 值の推移 : $5 \mathrm{mg} / \mathrm{dl}$ 前後で推移し, 10 年 目に急激な上昇を認めた(図 4 )。この間に繰り返し内 視鏡を含め画像検査をしているが，異常所見は認めな かった.

平成13年内科受診時胸部単純 CT：明らかなリンパ
節腫大を認めない（図 5 )。

血清 CEA 值上昇時の胸腹部 CT: 縦隔内および左 腎門部のリンパ節腫大を認めた（図 6 ).

腫大した頸部りンパ節の FNABでは，配列があり 腺管形成傾向を示す class V 像が認められ，粘液の産 


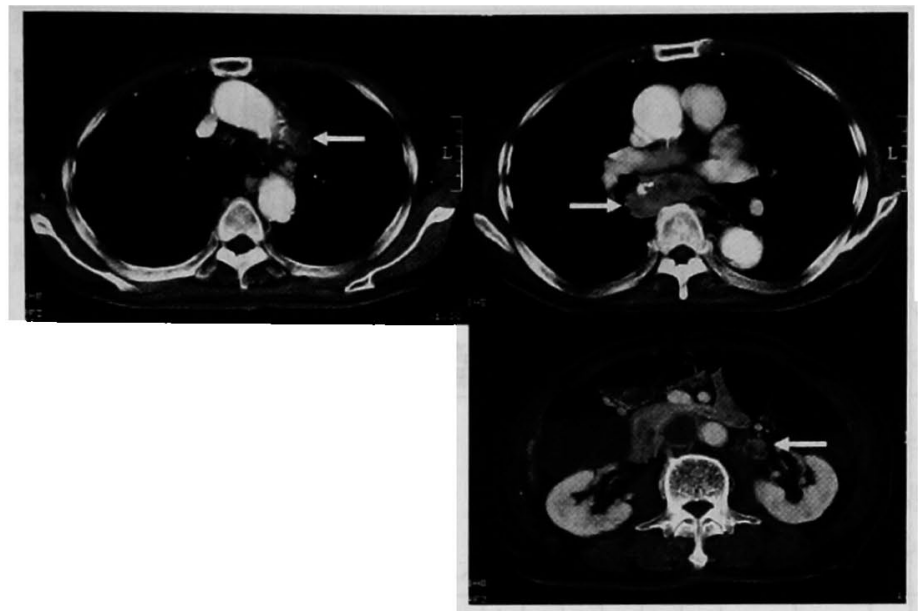

図 6 再発時胸腹部 CT 所見 : 佼隔内リンパ節, 左㹂門部リンパ節の腫大 を認める(矢印)。

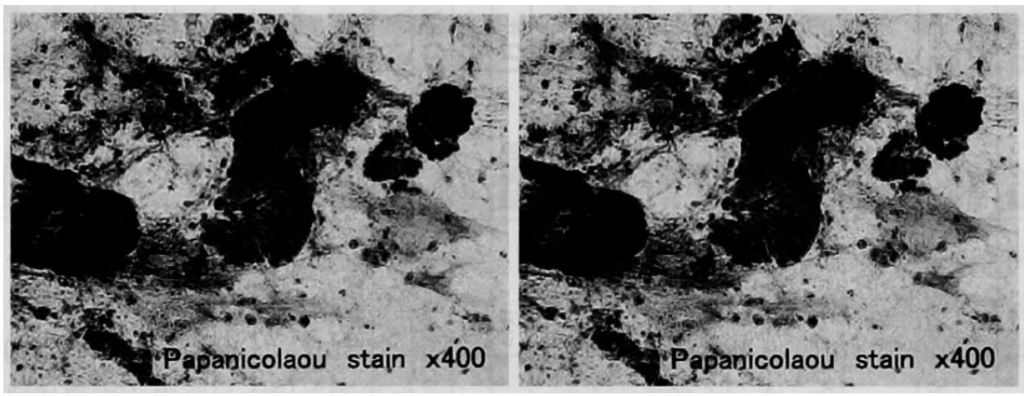

図 7 䫫部リンパ節生検病理所見：腺管形成傾 向と粘 液産生 傾向を示す (Papanicolaou 染色 $\times 400$ ).

表 1 粘液癌 stage IV の10年生存例 (1981-1992：追跡可 能(例)

\begin{tabular}{|c|c|c|}
\hline & stage I - III & stageIV \\
\hline 症例数 & 8 & 11 \\
\hline 年跲 & $58(38-71)$ & $60(44-77)$ \\
\hline 性別(男：女) & $5: 3$ & $5: 6$ \\
\hline \multicolumn{3}{|l|}{ 占翅部位 } \\
\hline 右側結腸 (C, A, T) & 1 & 2 \\
\hline 左側結腸 (D, S, ) & 2 & 4 \\
\hline 直腸 & 5 & 4 \\
\hline 肉眼型 $(1,2: 3.4 .5)$ & $7: 1$ & $6: 5$ \\
\hline 術後生存期間 $1-4$ 年 & 4 & 4 \\
\hline 5-9年 & 2 & 1 \\
\hline 10 年以上 & $\underline{1}$ & $\underline{1}$ \\
\hline
\end{tabular}

生を示唆する所見もみられた（図7）。

経過：本人, 家人と相談の上, 同年12月より CPT-11 と 5-FU, 1-LVの 3 剤併用全身化学療法を施行した。
表 2 大腸症術後10年生存症例 (1981-1992：追 跡可 能 例)

\begin{tabular}{lcc} 
& stage I - III & stageIV \\
\hline 症例数 & 94 & $\underline{4}$ \\
年龄 & $62(32-82)$ & $66.5(62-72)$ \\
性別 (男 : 女) & $56: 38$ & $3: 1$ \\
占拠部位 & & \\
$\quad$ 右側結腸 (C, A, T) & 24 & 2 \\
$\quad$ 左側結腸 (D, S, ) & 20 & 2 \\
$\quad$ 直腸 & 50 & 0 \\
肉眼型 $(1,2: 3)$ & $\underline{83}: 11$ & $4: 0$ \\
再発形式 (局所再発 : 遠隔転移) & $1: 7$ & $0: 1$ \\
無再発生存 & 86 & $\underline{3}$ \\
\hline
\end{tabular}

有害事象はほとんどみられなかったが，化学療法は奏 効せず，翌年 5 月に癌悪夜質でしくなった。

過去症例の検討：81年から92年に当科で経験した大 


\begin{tabular}{|c|c|c|c|c|c|c|c|c|c|c|c|c|c|c|c|c|c|c|c|c|c|c|c|c|c|c|c|c|c|c|c|}
\hline 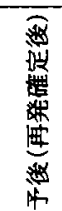 & $a$ & a. & r. & 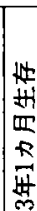 & a. & $r$. & 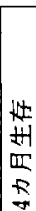 & $a$. & a. & 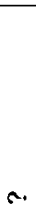 & 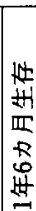 & 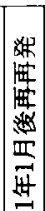 & r. & 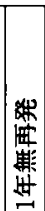 & a. & 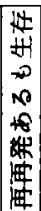 & a. & $\sim$ & 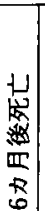 & 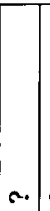 & $\sim$ & 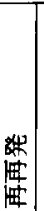 & & 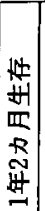 & $\begin{array}{l}1 \\
+4 \\
+1 \\
\text { 监 } \\
5 \\
0 \\
\text { 出 }\end{array}$ & $\approx$ & o. & $\sim$ & $\begin{array}{l}c \\
y \\
y\end{array}$ & c. & $\sim$ \\
\hline
\end{tabular}
点

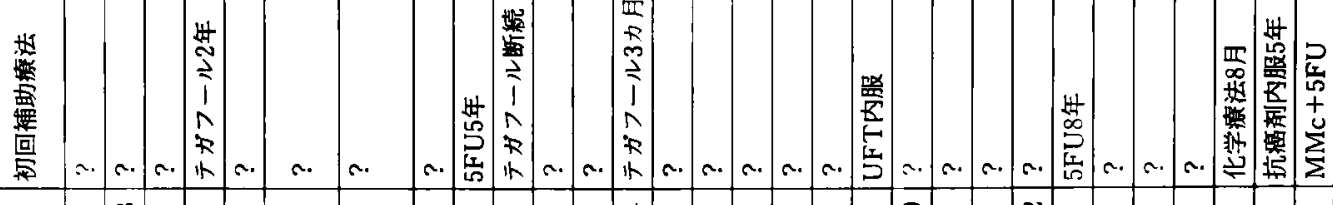

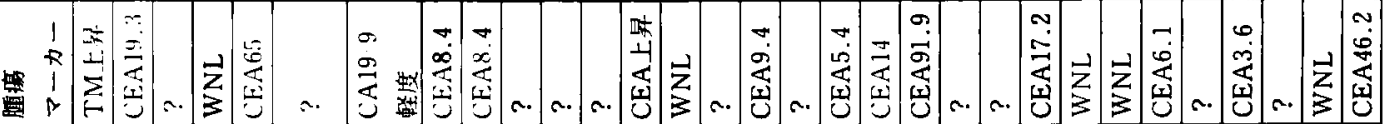

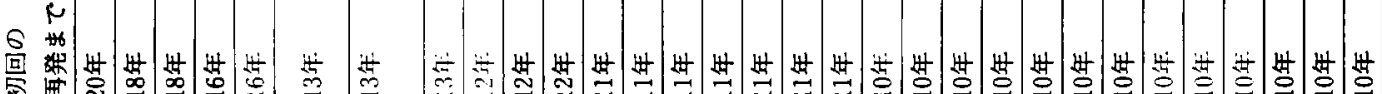

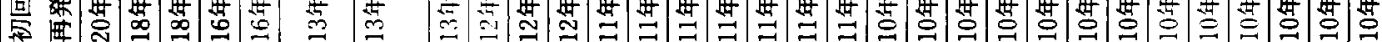
翡 至

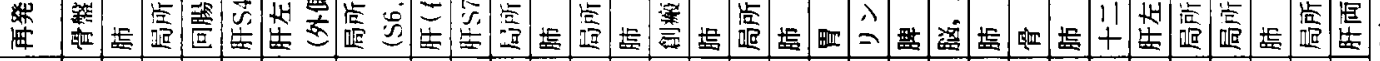
窝

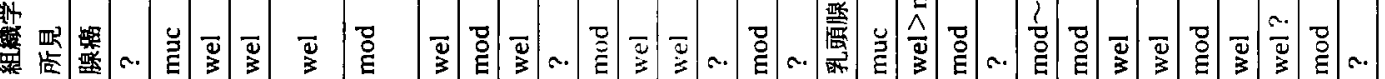

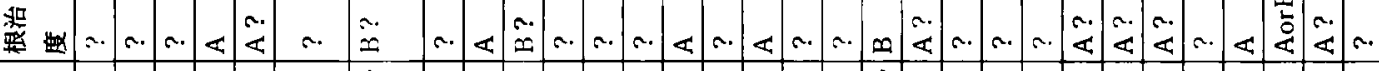

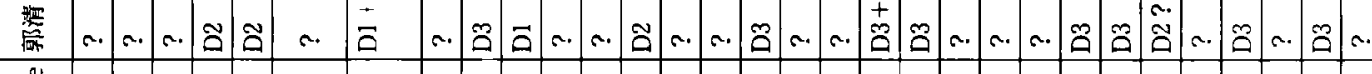

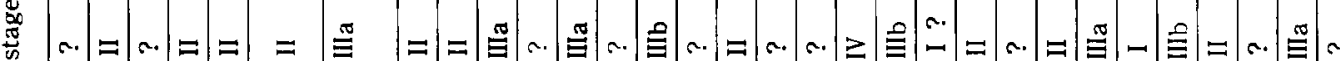

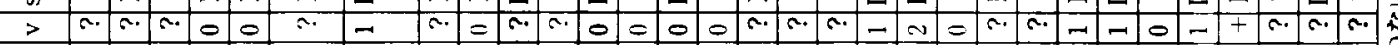

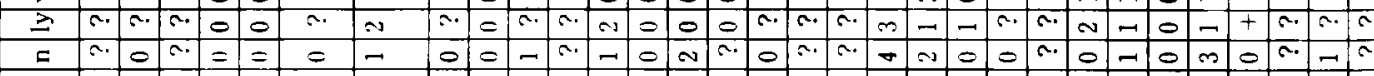

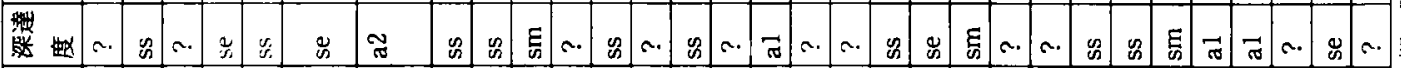

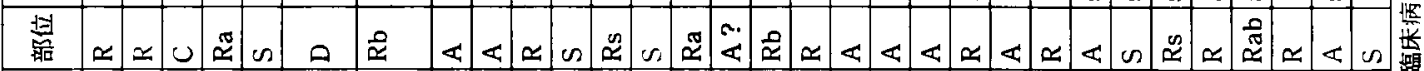

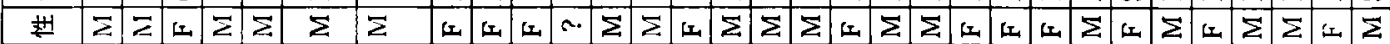

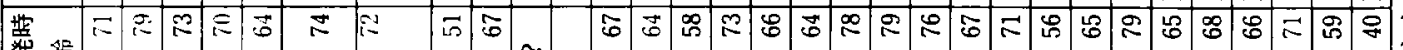
琛 $\infty$

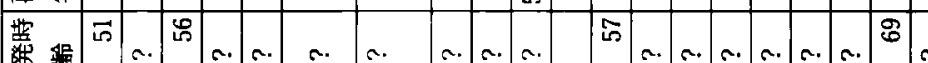

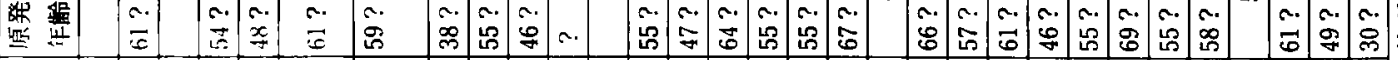

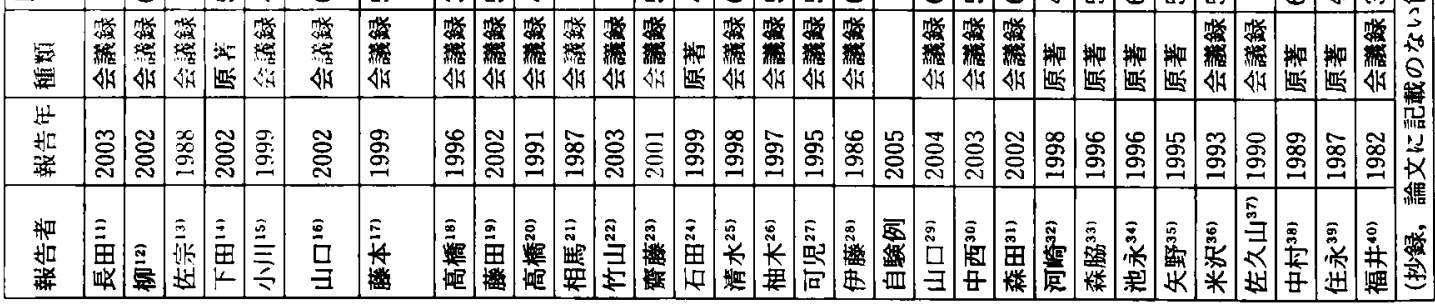


腸粘液癌21例のうち予後不明 2 例を除いた19例で倹討 した. 5 例が 5 年生存, 2 例が 10 年生存しているが, stage IVでの10年生存は 1 例であった（表 1 ）。なお全 大腸癌で10年生存が確認できたのは98例あるが，内 stage IV (自験例) は 4 例であり, 無再発生存例は 3 例 であった(表 2 )。全大腸癌でも10年経過後の再発例は みられなかった。

\section{考察}

本症例において特徵的なのは以下の点である，1， 高度に進行した粘液癌であるが長期生存が得られてい た. $2 ， 10$ 年間再発徴候がみられなかったにもかかわ らず， 1 年末満で急激に進行する病変を認めた。 3 ， 四重大リンパ節生検からは, 10年前の先行病変と類似し た病理学的所見が得られた。

それぞれについて，文献的考察を加える。

まず, 従来粘液癌の予後は通常の腺癌と比較し予後 不良とされており ${ }^{21}$ ，その要因については，右側結腸に 多く，浸潤傾向が強いため腫瘤を形成しがたく発見が 遅れるためと推察されている ${ }^{2(4)}$. しかし, 症例数が多 くないことから, 他の腺癌と比較して予後に相違はな いとする検討もみられる ${ }^{5 / 6)}$. 多くは 5 生率の悪さから 予後不良としているが, 治瘱切除例での生存率は非粘 液産生型腺癌に比へ遜色ないとする報告もあり》，10 年以上の長期生存例も見られる ${ }^{81}$.

次に，長期無再発生存後の再発について考察する。 一般に, 大腸癌特に結腸癌の術後再発までの期間は再 発例の約 $80 \%$ が 3 年以内で， 5 年以上経過後の再発は 少ないが，長期予後（5 年以上）に触れている検討で は, 老年者の生存例, stage IVで根治衍施行後, 再発を 繰り返しながらの生存例, 非治撚手術での生存例など

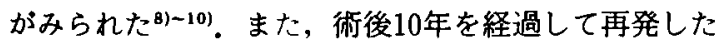
症例について,最近21年で検索しえた報告をもとに(表 3）にまとめた(1) 40). 詳細が不明な報告が多く, 年齢, 性別, 初発部位をはじめ明らかな傾向に乏しいが, 特 徵的な点を挙げるとすれば，転移再発部位では，肺転 移 (11例), 局所再発 ( 9 例), 肝転移 ( 6 例) が多く, リンパ節転移は少ない傾向であった．初発時の病理組 織学的所見で深達度 smであるものが 3 例, 臨床病期 が stage IIIbであるものが 3 例みられるものの, stage IVに達する高度進行癌切除例で，10年以上の経過後に 再発したと考えられた症例は，他になく，自験例は極 めて稀な症例と考えられる. 天池らの術後 6 年後再発 の症例では，CEA の継続した緩やかな上昇から，残存 癌組織が長い休眠状態 (dormant state) にありながら
も，䌅徐な分化が進行していたと考察されている41)こ の考察に従って考えると，本症例に扔いてはCEAの 急激な上昇がみられており， dormant state では分化 がほとんど行われず，なんらかの要因で再活動期には いったものと推察することが可能である。また，10年 経過後再発の報告には，抗癌㨈の長期投与により，再 発が抑えられた反面, 抗癌郕への感受性や, 癌細胞の 悪性度, 宿主免疫力などの变化が長期経過後の再発に 結びついたとの考察もあるが，確証は得られていな ( ${ }^{33} 3$ 35). 最近, 免疫染色や遺伝子解析での詳細な検討も 可能となりつつあり, 今後長期経過後の様々な変化も 検証されてくるものと思われる.

最後に，本症例は再発症例といえるかどうかについ て考察する. 原発巣不明な遠隔転移としては, 肺, 肝, 骨, 脳,リンパ節にみられることが多いとされる(2) 44). 頸部上部リンパ節転移巣の病理組織像は扁平上皮癌が 半数以上を占め, 頸部下部から縦隔リンパ節では腺癌

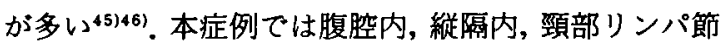
が同時期に腫大を認めており，靧部リンパ節の生検細 胞診が腺癌成分を示したことから， 3 領域のリンパ節 の腫大が，同一の腺癌を起源とした可能性は高いと考 えられる。またリンパ節原発性の腺癌としては, 原発 不明の縌隔リンパ節癌と診断された症例はあるもの の ${ }^{46 !}$, 異時性消化器癌の存在が確認できた症例の報告 はみられなかった。

自験例は，腫大リンパ節の切除ができず，免疫染色 などの検討がなされていないため，再発の確定診断に は至っていない. 従って, 大腸癌の再発ではない可能 性も否定はできないが, 前記の推論と, 明らかな他の 原発巣が確認できないこと，および原発巣と腫大リン パ節の病理組織学的所見の類似から，再発と判断する のが最も妥当であると考えた。

術後外来にて経過観察を行う場合， 5 年以上の長期 生存例でも再発の可能性があり，1 年末満の経過で急 激な進行がみられる症例があることから，少なくとも 年 1 回の全身検索を10年間継続する必要性が示唆され た.

\section{結 語}

術後10年でリンパ節再発をきたしたと思われる stage IV結腸粘液癌の 1 例を経験したので, 文献的考 察を加えて報告した。

なお, 本稿の要旨は第65回臨床外科学会総会で発表した。 


\section{文献}

1）大陽癌研究会編：大腸䍄取扱い規約. 改訂第 6 版, 金原出版，東京， 1998

2) Kanemitsu $Y$, Kato $T$, Hirai $T$, et al : Survival after curative resection for mucinous adenocarcinoma of the colorectum. Dis Colon Rectum $46: 160-167,2003$

3）岡 正朗, 内山哲史, 小倉 寛他：大腸粘液癌の 臨床病理学的特徵. 日臨外会誌 $53: 2347-2351$, 1992

4）小松信男, 河村正敏, 横川京児他：粘液結節を有 する大腸癌の臨床病理学的検討。日臨外会誌 $59: 623-628,1998$

5）鈴木章一, 関根 媇, 須田雍夫：大腸粘液癌の臨 床病理学的検討. 日消外会誌 $22: 2666-2670$, 1989

6) Minsky BD, Mies $C$, Rich TA, et al: Colloid carcinoma of the colon and rectum. Cancer 15 : $3103-3112,1987$

7）豊田和広, 中塚博文, 藤高嗣生 他：大腸低分化腺 癌・粘液癌の検討。外科 $65: 838-843,2003$

8）杉本昌之, 長谷川洋, 小増清二他：再発巣を 7 度切除し12年生存中の stage IV大陽粘液湟の 1 例. 日臨外会誌 $64: 1709-1713 ， 2003$

9）壬生隆一, 石川幹真, 水元一博他：老年者の消化 器進行癌の長期生存例 長期生存が得られた老年 者の進行大腸癌症例. 老年消器 $13: 175-179$, 2001

10）城 俊明，土屋周二，大木繁男他：大腸癌手術例 と遠隔成䋶 1973から1991年まての自験手術例 1503例について. 横浜医 $47: 567-572,1996$

11）長田俊一, 石井正之, 森田浩文他：直腸癌切除20 年後の骨盤内再発の1例. 日臨外会誌 $64: 2073$, 2003

12）柳 正和, 小川洋樹, 豊山博信 他：直腸癌術後 18 年目の肺転移切除の 1 例. 肺癌 $42: 648-649$, 2002

13）佐宗克久，伊藤 誠，岩井 彰他：術後18年で局 所再発をきたした大腸粘液癌の 1 例. Gastroenterol Endosc $30: 2109,1988$

14）下田雅史, 齍藤真文, 上田進久他：直腸癌術後 16 年目に発生した孤立性回腸転移の1例。臨外 $57: 549-552,2002$

15）小川智道, 谷 徹, 遠藤善裕他：術後16年目に みられた大腸癌肝転移の 1 切除例. 日外宝 68 ： 50,1999

16）山口峰一, 山本朗誉, 五十嵐雅彦他：大腸癌切除
後13年経過した孤在性肝転移の 1 切除例. 鳥取医 誌 $30: 45,2002$

17）藤本 緊，山本哲久，上野秀樹他：直腸癌根治術 後13年を経て吻合部ならびに肝転移再発をきたし た 1 例. 日本大腸肛門病会誌 $52: 896,1999$

18）高橋健治, 柏原營爾, 高倉籍尚地：大腸癌術後 13 年目に肝再発を認め手術を施行した 1 例。日臨外 会誌 57 (増刊号)：535, 1996

19）藤田 泉, 井上雄志, 山本雅一他：上行結腸癌術 後12年目に肝転移を認めた 1 例. 日臨外会誌 63 (增刊号) : 848, 2002

20）高橋俊毅, 吉永昌雄, 高橋䄙人他：術後約 12 年目 に局所再発をきたした $\mathrm{sm}$ 直腸癌の 1 例。医療 45 (増刊) : 420, 1991

21）相馬信行, 小松彦太郎, 高橋武宜 : S 状結腸癌切除 12年後に肺，気管支内転移を来し化学療法で治痹 したと思われる 1 症例. 肺癌 $27: 713 ， 1987$

22）竹山 茂，小林隆司，経田 疜他：術後11年目に 局所再発をきたした直腸癌の 1 例. 日癌治療会誌 $38: 628,2003$

23）啹藤克意, 高橋康宏, 橋田秀明他：S 状結腸癌治痹 切除11年後に発見・切除された肺転移の 1 例. 北 海道外科誌 $46: 183,2001$

24）石田雅俊, 濱路政靖, 宮崎 知他：術後11年を経 過して腹壁創疫痕に孤立性再発をきたした直腸癌 の 1 例. 臨外 $54: 706-708,1999$

25）清水 匡, 山本一道, 上野孝男他：大腸癌切除後 11年目に肺転移をきたした 1 切除例。肺癌 38 ： 360,1998

26）柚木靖弘, 大島 祐, 竹内仁司 他：直腸癌術後11 年 3 力月後に局所再発巣を切除し得た 1 例. 日臨 外会誌 58 (増刊号)：455, 1997

27）可児久典, 山川洋右, 丹羽 宏他：直腸癌術後11 年目に左上支下一下葉区 (S*) に肺転移をきたした 1 例. 肺癌 $35: 645,1995$

28）伊藤直史, 中井克雄, 大場 清他：11年を経て興 味ある再発を示した結腸痁の 1 切除例. 中部外科 会総会号 $22: 54,1986$

29）山口智弘, 山下哲郎, 小出一真他: 大腸癌術後 10 年目に脾転移をきたした 1 例. 日消外会誌 37 ： 1312,2004

30）中西喜嗣, 平 康二, 中村 豊他： $\mathrm{sm}$ 直腸癌術後 10 年目に譄・肺転移を診断しえた 1 例. 日臨外会 誌 $64: 527,2003$

31）森田利奈, 阿部忠義, 江川新一他：初回手術後12 年経過し出現した大腸癌膵転移の 1 例. 東北医誌 $114: 232,2002$ 
32）河崎雄司, 安田和人, 三上真影 他：術後10年て肋 骨へ転移し骨破境像と硬化像の混合像を呈した直 腸瘦再発の 1 例. 日胸臨 $57: 742-746,1998$

33）森脇義弘, 山腰英紀, 長堀 優他：上行結腸癌治 痹切除10年後に発見された孤立性肺転移の1切除 例. 日本大腸肛門病会誌 $49: 1074-1079,1996$

34）池永誠, 西八嗣, 立石 晋他：大腸癌術後10 年目に認められた転移性十二指腸癌の 1 例. 日臨 外会誌 $57: 1635-1640,1996$

35）矢野秀朗, 小西富夫, 根岸征示他：大腸 $\mathrm{sm}$ 癌術後 10年目に肝転移を来した 1 例. 手術 $49 ： 719-$ 723,1995

36）米沢 圭，小野寺久，今村正之他：術後10年を経 て局所再発した直腸癌の 1 例. 日臨外会誌 54(増 刊号) : 399, 1993

37）在久山陽, 徳田 - , 松繁 洋他：初回手術後10 年経過して局所再発した直腸癌の 1 例. 日外宝 $59: 291-292,1990$

38）中村治彦, 森山浩, 永井完治 他：直腸癌術後 10 年を経て出現した空洞性肺転移巣の 1 切除例. 日 胸臨 $48: 796-798,1989$

39）住永佳久，在藤知行，宮田道夫他：術後10年を経 過して興味ある再発形式を呈した大腸癌の 1 切除
例. 日外会誌 $88: 349-353,1987$

40）福井博行, 浜野恭一, 吉利彰洋他：S 状結腸癌術後 10 年目に発見切除し得た肝転移の 1 例. 日臨外会 誌 $43: 1291,1982$

41) 天池 寿, 谷口弘毅, 藤 信明他: 根治切除後 6 年経過して胃所属リンパ節への単独転移再発を認 めた横行結腸癌の 1 例. 日消外会誌 $37: 223-$ 228,2004

42）小柴寿人, 藤田宏行：多発性リンパ節転移をきた した原発巣不明腺癌の 1 例。日婦腫場会誌 18 ： $284-287,2000$

43）上吉原光宏, 石川 進, 小林克巳 他：原発不明緃 隔リンパ節癌の 1 手術例. 胸部外科 $54: 521$ 523,2001

44) Holmes FF, Fouts TL: Metastatic cancer of unknown primary site. Cancer $26: 816,1970$

45) 伊藤国明：原発不明がん (Cancer of unknown primary). 日本臨床腫瘍学会編, 臨床腫瘍学 (第 3 版), 癌と化学療法社, 東京, 2003, p1002-1015

46）真崎義隆, 五味淵誠, 田中茂夫他：原発巣不明肺 門縦隔リンパ節癌の本邦報告例の検討. 胸部外科 $50: 743-747,1997$

\title{
A CASE OF ADVANCED MUCINOUS COLON CANCER WITH LYMPH NODE RECURRENCE AFTER A 10-YEAR DISEASE FREE SURVIVAL
}

\author{
Kenshi HIRATSUKA, Akira TSUNODA, Kentaro NAKAO, \\ Tetsuya MIKOGAMI, Kosuke YAMADA and Mitsuo KUSANO \\ Department of General and Gastroenterological Surgery, Showa University School of Medicine
}

A 79-year-old man undergoing a right hemicolectomy for ascending colon cancer in August 1992, of which histopathological diagnosis was mucinous carcinoma, had been followed in the clinic after oneyear oral administration of anti-cancer drugs.

He had been recurrence free for ten years, until he developed diarrhea and body weight loss in November 2002. The level of serum CEA was elevated markedly. Upper gastrointestinal endoscopy and total colonoscopic findings showed no recurrence or other primary lesions. Chest and abdominal CT scans showed lymph nodes swelling at the para-aorta and mediastinal space. Fine needle aspiration biopsy (FNAB) of the supraclaviclar lymph node swelling showed class V. Because ductal formation and mucinous component were found out in the biopsied specimen, recurrence of the colon carcinoma was diagnosed.

Systemic chemotherapy was started in December 2002, but it was not effective. The patient died of cachexia in May 2003.

It is rare that for advanced colon cancer recurs after a long cancer-free period following an absolute curative surgery, and such a case has not been reported in the literature. This paper presents the case with bibliographical comments. 